This is an Open Access article, distributed under the terms of the Creative Commons Attribution licence (http://creativecommons.org/licenses/by/4.0/), which permits unrestricted re-use, distribution, and reproduction in any medium, provided the original work is properly cited.

\title{
An Undervalued Archaeological Resource: Social Aspects of Bronze Age Textile Production in the Eastern Iberian Peninsula
}

\author{
Ricardo E. Basso Rial ${ }^{1}$ (i), Francisco Javier Jover Maestre $^{1}$ (1) and \\ Juan Antonio López Padilla ${ }^{2}$ (1) \\ ${ }^{1}$ Research Institute of Archaeology and Heritage, University of Alicante, Spain \\ ${ }^{2}$ Archaeological Museum of Alicante, Spain
}

According to Childe, the Bronze Age in Europe is thought to be the first 'golden age' in European history. The development of metallurgy, clearly associated with the production of weapons, and the expansion of exchange networks covering all types of goods are considered essential in the process of consolidation of social elites, and, by extension, of social inequalities. The significance of textile production has, however, been undervalued as a specialized craft and as a manufacturing process that creates cultural differences and signals social inequalities. Being associated with domestic contexts rather than with specialized workshops, textile production in the eastern Iberian Peninsula has been underestimated; it is addressed here, as is its potential importance in societies immersed in a process of social stratification.

Keywords: textile production, Bronze Age, eastern Iberian Peninsula, linen, wool, esparto grass

\section{INTRODUCTION}

Research into the development of Bronze Age societies in Europe and the Mediterranean has emphasized the importance of trade associated with the development of metallurgy (e.g. Childe, 1958; Briard, 1997; Kristiansen \& Larsson, 2005; Earle et al., 2015). The presence of a wide range of copper and bronze artefacts, particularly weapons, in the archaeological record has reinforced the image of the Bronze Age as the period in which warrior elites emerged and social stratification began (e.g. Gilman, 1981; Lull, 1983; Chapman, 1991; Harding, 2000).

This perspective has, however, led to a certain undervaluing of the importance of other crafts in the processes of social development, including, in our opinion, textile production. Indeed, textile production-especially weaving and sewingrequires great skill and ability, as well as many hours of work. Such attributes are usually associated with craft specialization and the technical division of labour.

While studies carried out in the Eastern Mediterranean and elsewhere in Europe have highlighted the economic and social importance of textiles (e.g. Lucas \& Harris, 1962; Barber, 1991; McCorriston, 1997; Killen, 2007; Gleba, 2008; Harris, 2012; Andersson Strand \& Nosch, 2015; Frei et al., 2017; Bender Jørgensen et al., 2018; Sabatini et al., 2018; Sabatini \& Bergerbrant, 2019), textiles have been 
undervalued and gone almost unnoticed on the Iberian Peninsula. Research conducted in its south-eastern part has identified three cultural groups in the region: El Argar, the Valencian Bronze Age culture and the Motillas or La Mancha culture (Figure 1). All developed between 2200 and $1500 \mathrm{cal} \mathrm{BC}$, with a diversity of occupation sequences, and with different degrees of social development observable in differences in the structure of settlements, demographic concentrations, and social practices. Among them, the best known is El Argar (Siret \& Siret, 1890; Lull, 1983; Chapman, 1991; Lull et al., 2009; Aranda et al., 2015) thanks to the long research history and the large quantity and high quality of the excavations and studies undertaken there. The aim of this article is to evaluate the archaeological evidence for textile production and its importance in Bronze Age societies in the eastern Iberian Peninsula.

\section{Theoretical Considerations}

Activities related to textile production in the Iberian Peninsula have not usually been taken into consideration in the discourse to explain the emergence of processes of specialization and the social division of labour, or the development of social hierarchies. We believe that it has been underestimated for a variety of reasons, including the scarcity of textile evidence preserved in the archaeological record and because textile production, particularly spinning and weaving, has been considered a female and therefore a domestic activity based on ethnographic and ancient iconographic sources.

The nature of textile production, however, implies the participation of a large number of people involved in the multiple tasks associated with obtaining wool, flax, and other plant fibres, their processing and treatment, and the production of a wide variety of products. In addition, this is an activity that requires a large and varied number of tools, from awls and bone or metal needles to clay spindle whorls and loom weights, and wooden warp-weighted looms. Their manufacture would in turn have required the participation of numerous craftspeople (Costin, 2005, 2013). The labour and collaboration required for these processes would have needed efficient coordination and planning by at least part of the community or group.

If these activities were undertaken within a household, extended family group, or lineage, the aim would have been to meet the needs of all the members of the group, with any surplus used in exchange for other goods. If, on the other hand, it was organized within an early class-based society, both the raw materials, whether processed or not, and the textiles or even the finished garments, could have served as tribute (Killen, 2007; Algaze, 2008).

Textile production, therefore, does not appear to have been an activity of little importance. On the contrary, it brings together a series of processes, sequentially linked, including those that cover basic needs but which also go beyond merely providing clothing. Clothing, but also insignia such as pennants, are elements of group identification as well as supports for ideological and symbolic meanings; and they continue to be used in present-day societies as elements of group or community expression (Bender Jørgensen et al., 2018). To produce textiles involves a wide range of activities: cultivation, animal husbandry, the collection of wild resources, and crafting (Gleba, 2008; Gleba \& Mannering, 2012; Costin, 2013; Andersson Strand \& Nosch, 2015). These tasks require specific spaces for the storage of raw materials, as well as their treatment 


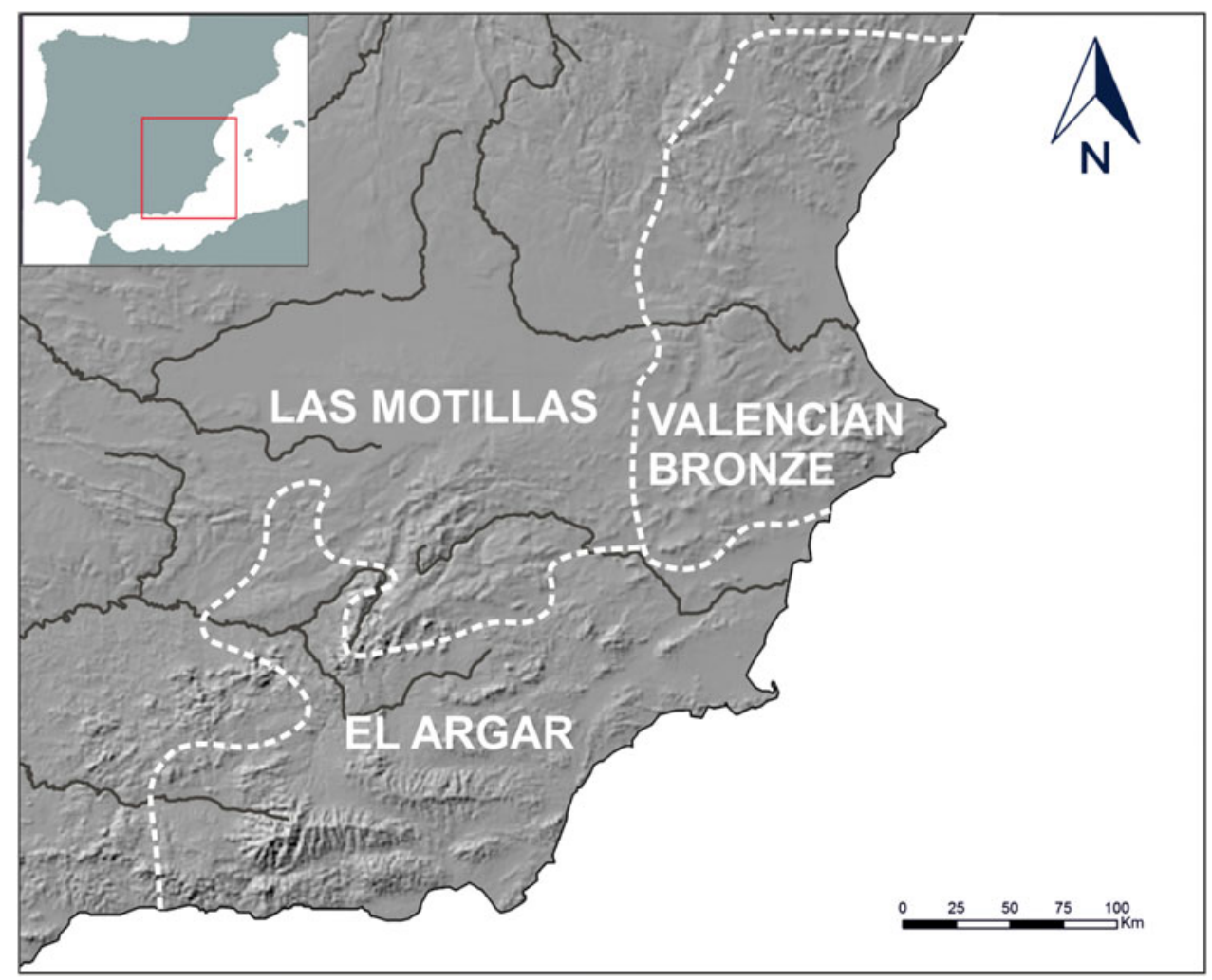

Figure 1. Distribution of Bronze Age archaeological cultures of the eastern Iberian Peninsula.

and manufacture (Jover \& López, 2013). Therefore, textile production entails a complex chain of processes which are connected spatially, temporally, and technologically. This requires careful planning and organization, from producing and managing the raw materials, to making the yarn, and the final processes of preparing the fabrics, fashioning, and sewing the garments (Costin, 2013). Textiles would, therefore, have been high-value goods (Risch, 2002), especially considering the time invested in their preparation. Moreover, they could acquire an exchange value, given their social role, in addition to their durability, quality, and ease of storage and transport.

Among the eastern Iberian Bronze Age societies, and particularly the Argaric culture, there are various considerations to address, including to what extent the production, exchange, and distribution of textiles may have been under the control of an incipient elite and how forms of appropriation of such goods may have been carried out within domestic groups.

\section{Evidence of Textile Production}

Currently, there are more than a hundred sets of archaeological records associated with textile production, which can be grouped in two categories. The first encompasses funerary contexts, where the remains of linen fabrics used as shrouds or to wrap metal objects deposited as grave goods have been found (Alfaro, 1984, 2012; Hundt, 1991). The second category includes the household spaces within 
settlements, with evidence of implements associated with textile production, such as loom weights, spindle whorls, thread coils, spools, spacers, and awls. Further evidence includes the remains of flax stems and seeds, and the charred remains of other species, found on the floor of burned houses (Jover \& López, 2013).

\section{Funerary ConTeXts}

Almost all the garments and fabric fragments recorded in the Iberian Peninsula are made of linen (flax). One exception is the possible wool cap and woven esparto grass leggings found in Grave 121 at the El Argar-culture site of Castellón Alto in the province of Granada dated between 1800 and $1600 \mathrm{cal} \mathrm{BC}$. Here, a carbonized material was also found, perhaps the residue from the burning of a skein of wool (Contreras et al., 2000: 89; Molina et al., 2003; Rodríguez-Ariza \& Guillén, 2007: 67). These rare finds contrast with almost one hundred recorded fragments of linen garments, shrouds, or sheets (Siret \& Siret, 1890; Alfaro, 1984; Hundt, 1991): currently, ninety-eight examples are known from twenty-two sites, almost all of which belong to Argaric contexts (Jover \& López, 2013). The only exceptions outside the Argaric cultural area are fragments found in an infant burial in Cave no. 9 of Monte Bolón in the province of Alicante dated to around $1700 \mathrm{cal} \mathrm{BC}$ (Soler et al., 2008; Jover \& López, 2013) (Figure 2) and a small fragment of fabric found in Stratum IV of dwelling VII in Cabezo Redondo, also in the province of Alicante (Soler, 1987: 46). The great majority of the surviving linen fragments come from burial contexts, where they were preserved thanks to direct contact with metal objects. Most have Z-twisted threads and their thickness ranges widely between 0.2 and $1 \mathrm{~mm}$, although those between 0.3 and $0.5 \mathrm{~mm}$ predominate. Notable variations are also found in terms of density (threads per centimetre) and in the number of threads of the warp with respect to that of the weft. Their number is usually between $4 / 7$ and $14 / 24$ per $\mathrm{cm}^{2}$, although a frequency between 12 and 14 per $\mathrm{cm}^{2}$ is usually repeated (Alfaro, 1984; Hundt, 1991).

There is very little evidence of possible fibre or fabric dyeing. One of the few examples of fabrics whose analysis revealed pigmentation remains was found in a burial in Cueva Sagrada I in Lorca (Murcia). These fragments have a reddish colour obtained by the deliberate dyeing of the fabric with madder (Rubia tinctorum L.) (Alfaro, 2005: 237). The burial, dating to just before the Bronze Age, also contained a possible handloom with several fragments of linen thread around it and a wooden stick, interpreted as a spinning spindle, both deposited as grave goods next to the textile remains (Alfaro, 2005: 230-34). This is the only evidence of textile tools deposited in graves dating to the end of the third millennium and the second millennium BC. Among the more than one thousand Argaric graves investigated, tools directly associated with textile production (spindle whorls or loom weights) are surprisingly absent. This is even more remarkable when compared to the evidence from Iron Age sites, in which clay whorls become one of the most important items found in women's graves (Rafel, 2007).

In Argaric female burials, it is however quite common to find tools associated with textile production other than spindle whorls or loom weights. According to a theory proposed some years ago by Risch (2002: 75), some men's social roles and position in political decision making was emphasized by their association with weapons, while the importance of women in social production processes, specifically in connection with garment production, 


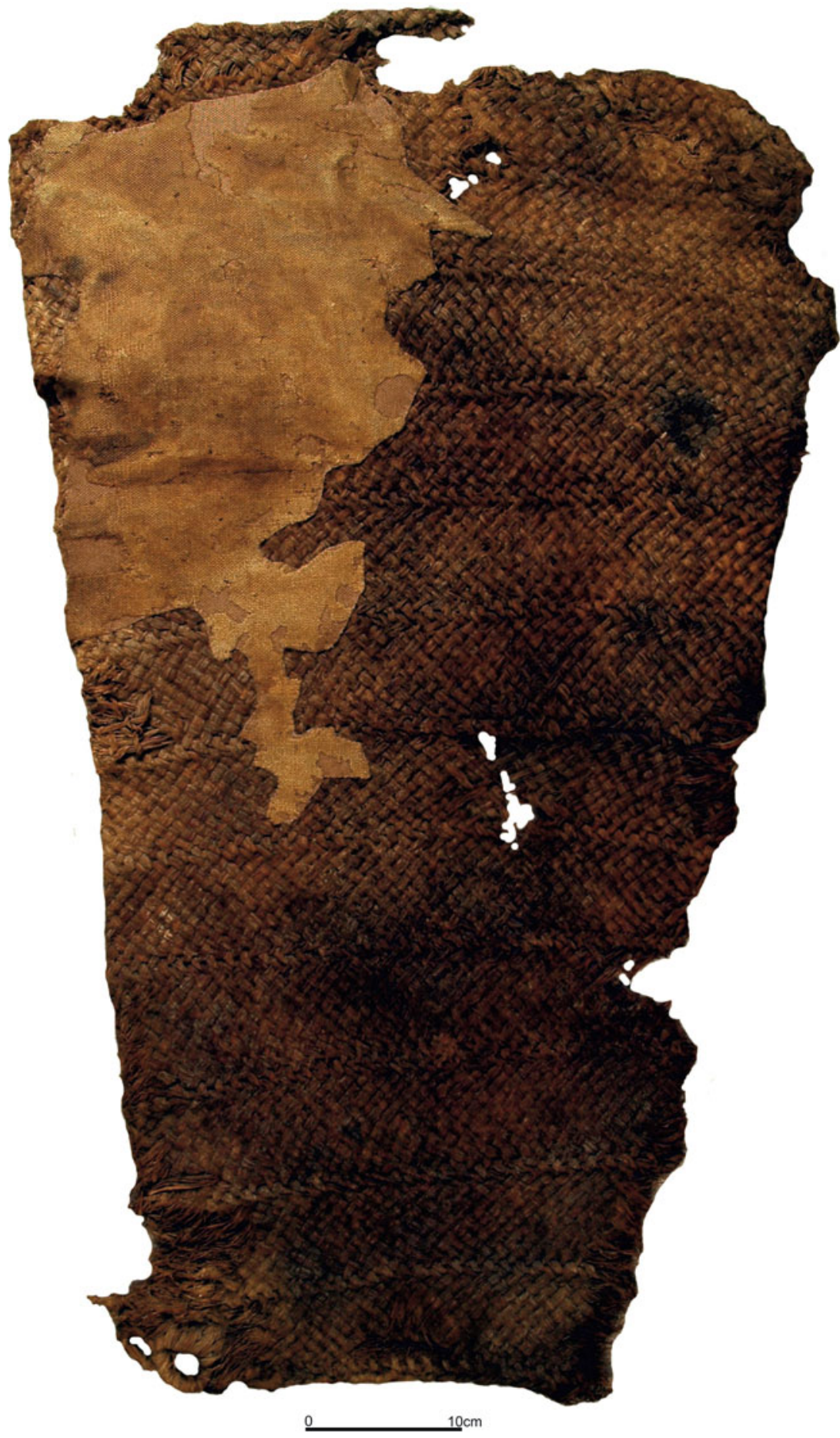

Figure 2. Basket of esparto grass and linen fabric from Cave no. 9 at Monte Bolón. 
was signalled through their association with metal awls, knives, and daggers found in their graves. Women would have played fundamental roles in the economy due to their association with textile activities. In this context, evidence of tooth wear, in the form of incisors with $\mathrm{U}$ or $\mathrm{V}$ shaped grooves among some women buried at Cabezo Redondo (Romero, 2016: 85-86) (Figure 3) and Castellón Alto (Lozano et al., 2020), has been interpreted as having been related to spinning or to the processing of fibres. Similar evidence has also been documented in other areas of the Iberian Peninsula (Fidalgo et al., 2019).

\section{Domestic ConTeXts}

Little evidence of fibre remains has been recorded in domestic settings; but wool, flax, and other plant fibres, such as rush, bulrush and, above all, esparto grass, have nevertheless been recovered.

Until now, wool has only been identified in Castellón Alto, in the form of a mass of carbonized matter with a foam-like appearance (Contreras et al., 2000: 89; RodríguezAriza \& Guillén, 2007: 67). Rushes, on the other hand, have been recorded on bobbins of thread stored at the settlement of Terlinques in the province of Alicante (Jover et al., 2001) (Figure 4A and B).

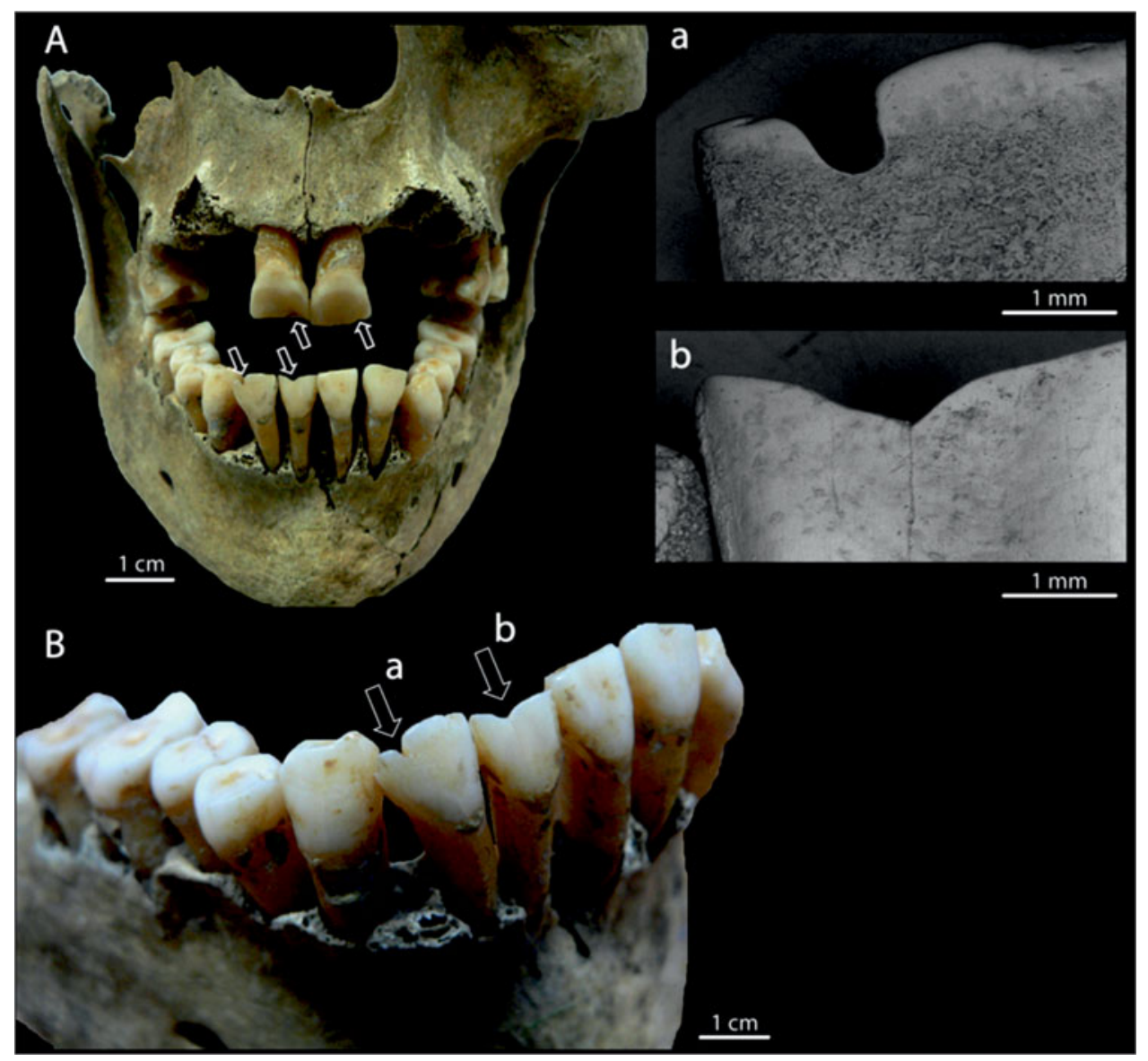

Figure 3. Incisors with $U$ - or $V$-shaped grooves belonging to a young woman buried at Cabezo Redondo (Romero, 2016: 86). Photograph reproduced by permission of A. Romero. 

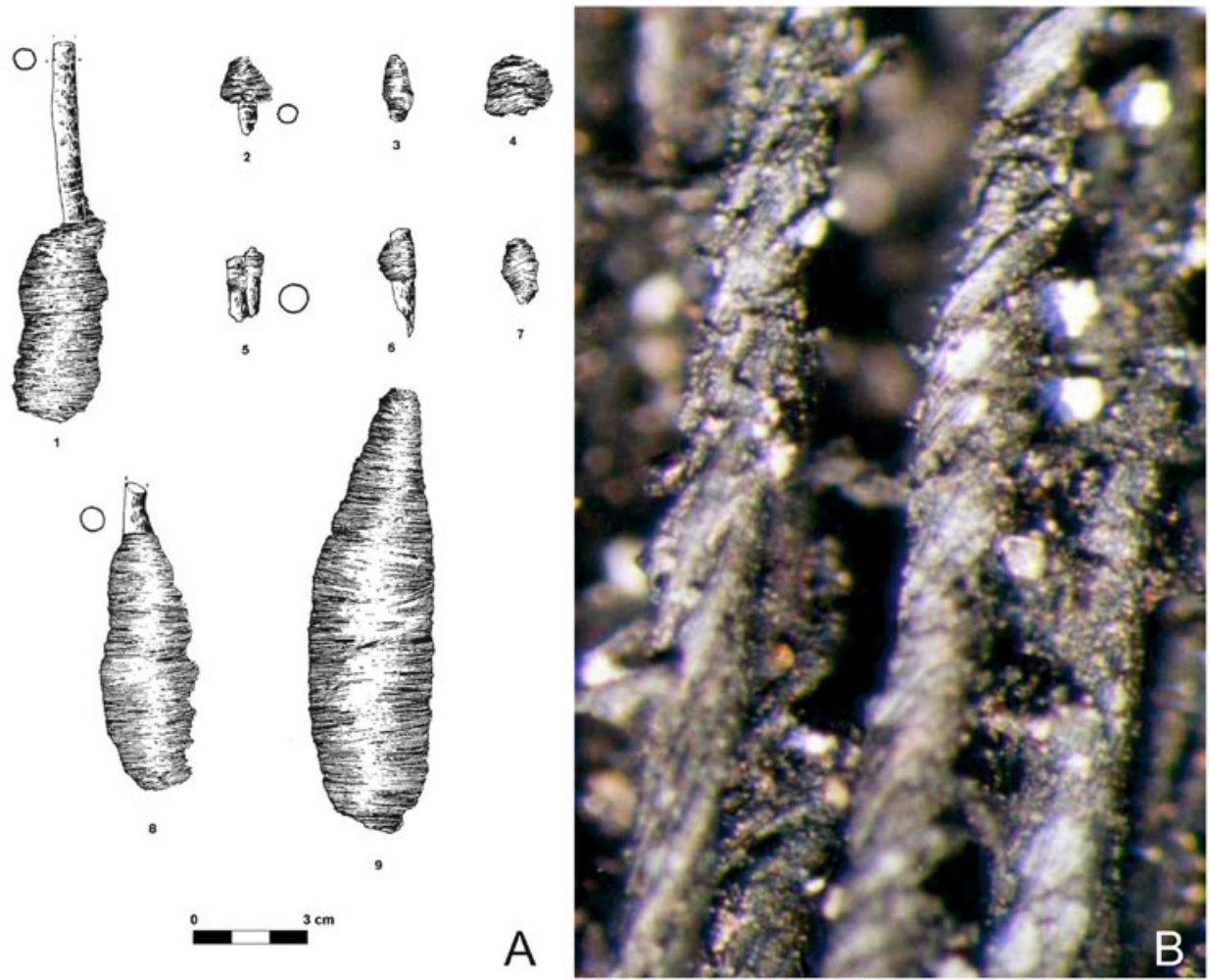

Figure 4. A: set of rush fibre bobbins from Terlinques. B: detail of the thread on bobbin no. 9.

Another similar bobbin or spindle with yarn was documented at Motilla de Santa María del Retamar in the province of Ciudad Real (Galán \& Sánchez Meseguer, 1994: 99), although in this case the fibres were not identified.

Flax and esparto have been found in almost one hundred archaeological contexts (Ayala \& Jiménez, 2007; Jover \& López, 2013: 166-67, fig. 20). Flax seeds have been recovered at a number of sites (Buxó \& Piqué, 2008; Lull et al., 2015a, 2015b) and, to a lesser extent, as fibre and fabrics on sites such as El Oficio (Alfaro, 1984: 123) and Castellón Alto (Rodríguez-Ariza \& Guillén, 2007: 63) in the El Argar region, Cabezo Redondo (Soler, 1987) in the Valencian Bronze Age region, and El Cerro del Cuchillo (Hernández \& Simón, 1993) in the La
Mancha Bronze Age region. A similar situation is documented among finds of esparto, which was not only used in rope making, basket weaving, and as a building material, but also in fashioning garments (Molina et al., 2003).

The archaeological record indicates that esparto grass, which grows naturally in the semi-arid climate of the south-east and east of the Iberian Peninsula, was the main fibre used in basketry (Figure 5) and rope making (Jover \& López, 2013), resulting in a wide range of items associated with storage and transport, agricultural tasks, cattle husbandry, house building, clothing, and footwear. Baskets, mats, and ropes used in construction and as handles for ceramic vessels are among the best-preserved (generally charred) remains, although sandal soles have also 


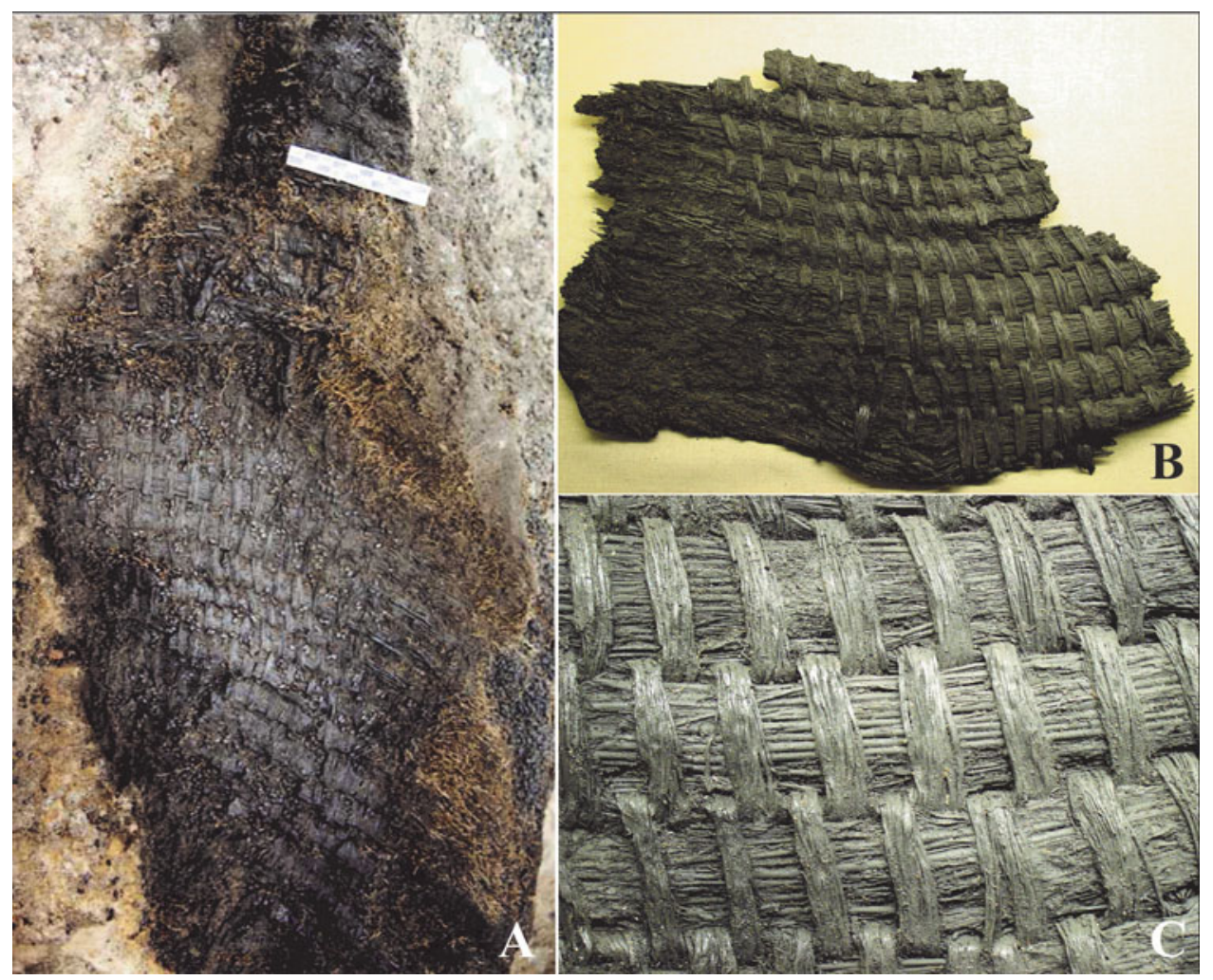

Figure 5. $A$ and B: basket of esparto grass containing cereals and bobbins, found in Terlinques. $C:$ detail of the crossed weft of raw and crushed esparto in the basket.

been documented in Cabezo Redondo (Soler, 1987: 78) and in Castellón Alto (Rodríguez-Ariza \& Guillén, 2007: 69). Excavations carried out from the 1950s to the present on numerous sites with chronological sequences from 2100 to $1300 \mathrm{cal} \mathrm{BC}$ show their abundance and quality (Soler, 1987; Jover et al., 2001; Rodríguez-Ariza \& Guillén, 2007; Jover \& López, 2013). Esparto grass was clearly an extremely important raw material, even though its supply, selection, preparation, and manufacture were probably undertaken strictly at a household level.

Tools for producing textiles, such as needles, bone and metal punches, copper knives and daggers, spacers, and spools, have also been found on several of the sites mentioned above. These objects were used in various tasks such as basketry, weaving, and sewing (Jover \& López, 2013).

Spindle whorls and loom weights are the most common objects most directly associated with spinning and weaving that survive in the archaeological record (Table 1). In the Iberian Peninsula, spindle whorls date back to the Late Neolithic (López Mira, 1995), but their use spread throughout the south-east from the third millennium BC onwards. There is considerable variation in the form of spindle whorls, in terms of morphology, weight, and material. Clay, stone, antler, and bone spindle whorls are all documented. In the second millennium $\mathrm{BC}$, most whorls were made of clay and the most common shapes were discoidal and biconical. Discoidal whorls, the most common 
Table 1. Bronze Age periods in eastern Iberia with textile tools and products in radiocarbon-dated contexts.

\begin{tabular}{|c|c|c|c|}
\hline Chronology & Textiles and tools & $\begin{array}{l}\text { Main }{ }^{14} \mathrm{C} \text {-dated } \\
\text { settlements }\end{array}$ & References \\
\hline 2200-2100 cal вС & $\begin{array}{l}\text { Linen fabrics } \\
\text { Wooden spindle }\end{array}$ & Cueva Sagrada I & Alfaro, 2005 \\
\hline $\begin{array}{l}2100-1800 / 1750 \mathrm{cal} \\
\text { BC }\end{array}$ & $\begin{array}{l}\text { Linen fabrics } \\
\text { Wooden spindle } \\
\text { Spindle whorls } \\
\text { Oblong and cylindrical loom weights } \\
\quad(4 \text { holes })\end{array}$ & $\begin{array}{l}\text { Tabayá } \\
\text { Terlinques } \\
\text { Caramoro I } \\
\text { Tabayá } \\
\text { Tira del Lienzo } \\
\text { Rincón de Almendricos } \\
\text { Barranco Tuerto } \\
\text { Cabezo de la Escoba } \\
\text { Cerro del Cuchillo } \\
\text { Serra Grossa } \\
\text { Lloma de Betxí }\end{array}$ & $\begin{array}{l}\text { Jover \& López, } 2013 \\
\text { Jover et al., } 2001 \\
\\
\text { Jover et al., 2019 } \\
\text { Jover \& López, } 2013 \\
\text { Lull et al., 2015a } \\
\text { Ayala, 1991 } \\
\text { Basso, 2018b } \\
\\
\text { Hernández \& Simón, } \\
\text { 1993 } \\
\text { Basso, 2018b } \\
\text { De Pedro, 1998 }\end{array}$ \\
\hline $1750-1600$ cal вС & $\begin{array}{l}\text { Linen and esparto fabrics } \\
\text { Wool fabrics } \\
\text { Spindle whorls } \\
\text { Cylindrical loom weights ( } 2 \text { holes) }\end{array}$ & $\begin{array}{l}\text { Castellón Alto } \\
\text { Cueva } 9 \text { Monte Bolón } \\
\text { Castellón Alto } \\
\text { Tabayá } \\
\text { La Almoloya } \\
\text { Terlinques } \\
\text { Peñalosa } \\
\text { Castellón Alto } \\
\text { La Almoloya }\end{array}$ & $\begin{array}{l}\text { Molina et al., } 2003 \\
\text { Soler et al., } 2008 \\
\text { Molina et al., } 2003 \\
\text { López Mira, 1995 } \\
\text { Lull et al., 2015b } \\
\text { Jover \& López, } 2013 \\
\text { Contreras, 2000 } \\
\text { Contreras et al., } 2000 \\
\text { Lull et al., 2015b }\end{array}$ \\
\hline $1600-1300$ cal вС & $\begin{array}{l}\text { Linen and esparto fabrics } \\
\text { Spindle whorls } \\
\text { Cylindrical loom weights ( } 1 \text { hole })\end{array}$ & Cabezo Redondo & $\begin{array}{l}\text { Soler, } 1987 \\
\text { López Mira, } 1995 \\
\text { Hernández et al., } 2016\end{array}$ \\
\hline
\end{tabular}

type from the Copper Age to the middle of the second millennium $\mathrm{BC}$, have been recorded at various Argaric sites, such as Zapata, El Argar, and Fuente Álamo (Siret \& Siret, 1890). Examples have also been found on sites on the periphery of the Argaric area, such as at Cabezo Redondo (Soler, 1987: 112). Also included in this group are spindle whorls made from deer antler (Basso \& López, 2019), which have been widely recorded from the middle of the second millennium cal BC onwards, at sites such as Cabezo Redondo (López Padilla, 2011) and La Almoloya in the El Argar region (Lull et al., 2015b: 102). Biconical whorls, or rarer examples with an irregular crosssection, similar to a bi-truncated cone, all made of clay, have been found at El Argar, Cabezo Redondo, Laderas del
Castillo, San Antón de Orihuela, Tabayá, and Terlinques (Jover \& López, 2013).

Generally speaking, spindle whorls are relatively rarely found on excavated Bronze Age sites. It may be that some were made of wood or other perishable materials, or a spinning technique called splicing that did not require a spindle was used (Basso, 2019; Gleba \& Harris, 2019). Be that as it may, the situation changed significantly in the Late Bronze Age, and particularly in the Iron Age, when whorls began to be commonly deposited as grave goods in female burials (Rafel, 2007).

By contrast, loom weights are encountered far more frequently. They are usually made of clay and vary in shape (oblong, ovoid, or cylindrical), size, weight, and number of perforations (between one and four) (Jover \& López, 2013; Basso, 2019). 
They are often found in variable quantities, in piles or in more isolated groups of fewer pieces, within domestic spaces or in open areas on settlements.

It appears that warp-weighted looms were the most common type of loom documented archaeologically (Alfaro, 1984: 94-106; Contreras et al., 2000). The discovery of groups of weights at various settlements, some aligned and associated with burnt rectilinear timbers (Figure 6) and some even with spindle whorls or remains of yarn nearby, has enabled us to infer the presence of looms and textile production areas in different contexts. However, the presence of a set of weights does not necessarily imply the existence of a loom. In some cases, the weights may simply have been stored, while, in others, they may have been reused to construct ovens or other structures (Basso, 2018a).

More than twenty sites with concentrations of loom weights are currently known (Figure 7). On some of these, including
Tira del Lienzo (Lull et al., 2015a: 194), Los Cipreses, and Lloma de Betxí (De Pedro, 1998), these concentrations appeared in a single building. On other sites, such as La Almoloya (Lull et al., 2015b: 104), Peñalosa (Contreras, 2000: 129), and Cabezo Redondo (Soler, 1987), large concentrations have been recorded in several buildings, and in some of these, as in Peñalosa, loom weights were found in unequal numbers, in ten different locations within the settlement.

Significant differences become evident when the numbers of loom weights in the concentrations are compared to the types of weights found. Generally, the large heavy loom weights with four perforations, which are earlier and date between 2200 and 1750 $\mathrm{BC}$, appear concentrated in small groups of between two and ten weights (Basso, 2020). In some cases, however, as in Lloma de Betxí (De Pedro, 1998) (Figure 8) and Castell d'Almizra, clusters of more than twenty stacked loom weights have been found. These could be interpreted as stored

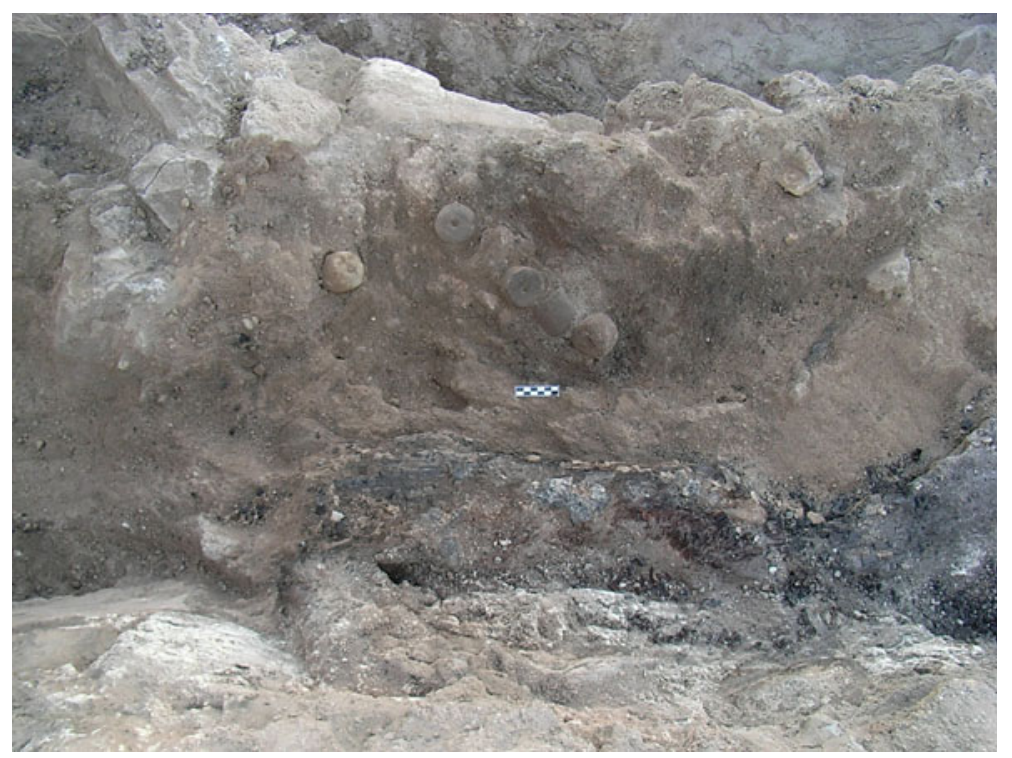

Figure 6. Concentration of loom weights found next to a carbonized beam in Cabezo Redondo. Photograph reproduced by permission of M.S. Hernández. 


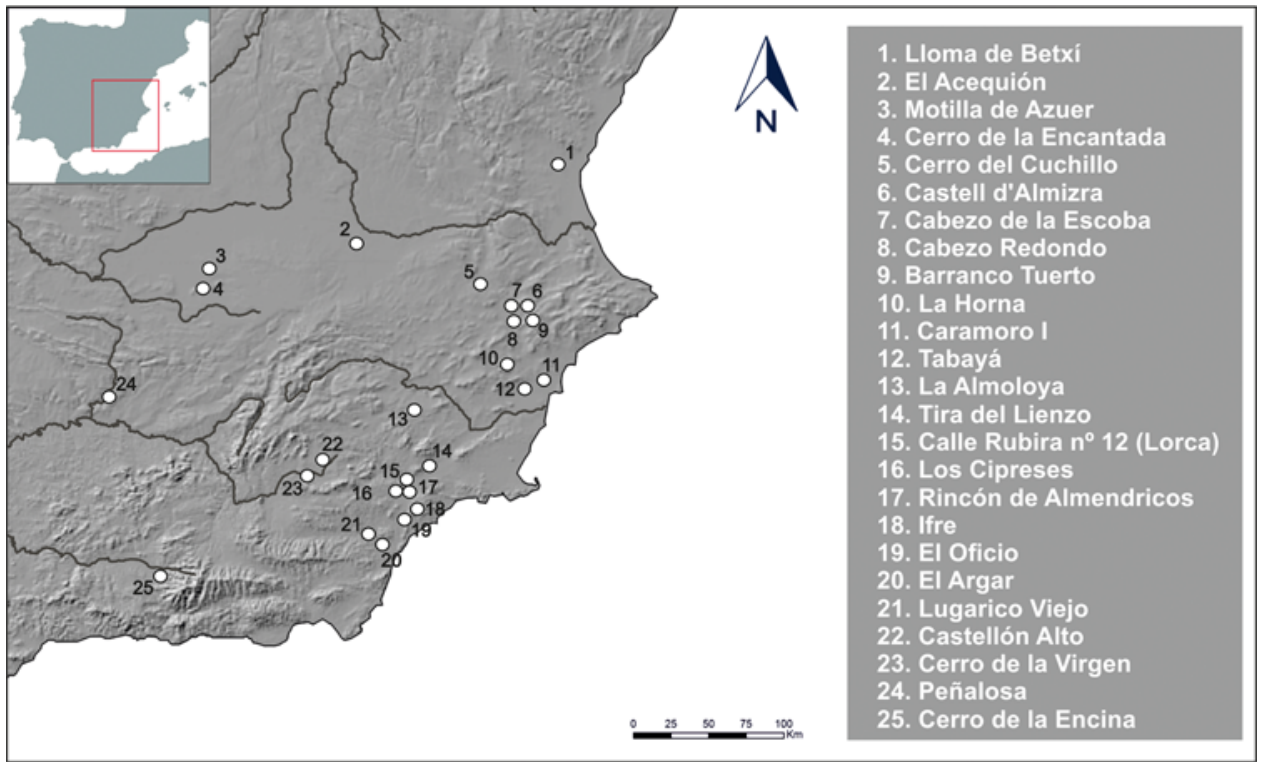

Figure 7. Distribution of archaeological sites with loom weight concentrations.

weights, rather than indicating the position of a loom (Basso, 2018a).

From 1800/1750 cal BC onwards, we begin to see changes in the morphology, size, and weight of the loom weights, and in the numbers found together. These later weights tend to be cylindrical, smaller and lighter, and with fewer perforations. Often groups of more than twenty weights have been found. Observing this change has led us to consider the number of loom weights required to operate a warp-weighted loom. In the case of large oblong loom weights, recent studies suggest that no more than about ten weights

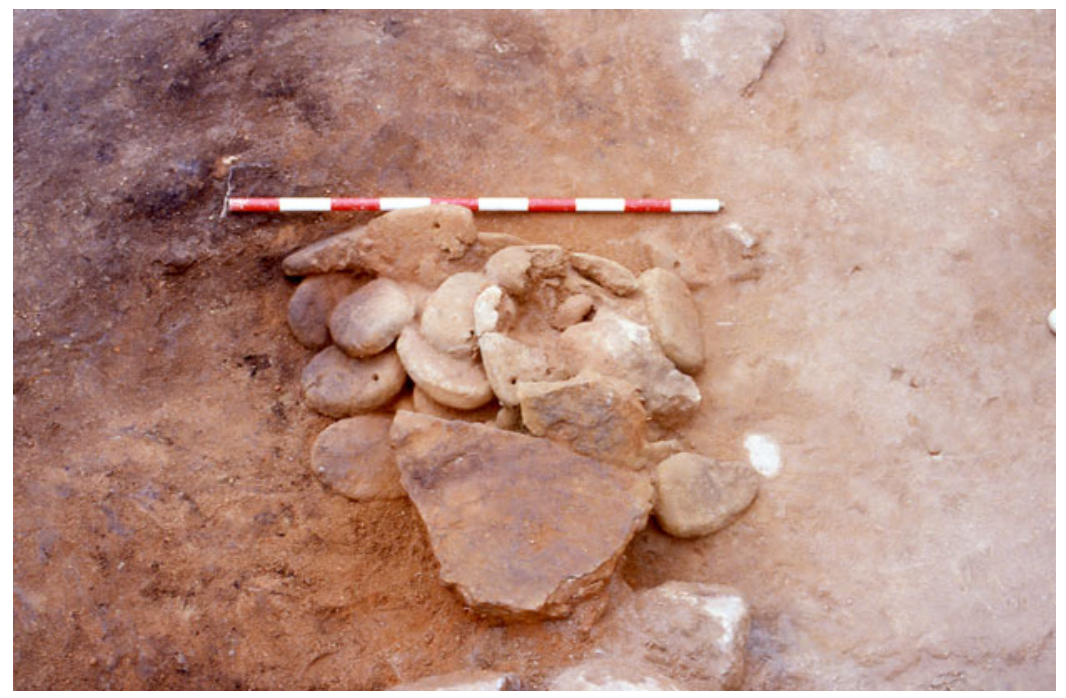

Figure 8. Concentration of oblong loom weights from the settlement of Lloma de Betxi. Photograph reproduced by permission of M.J. De Pedro. 
were required (Basso, 2018b: 61, 2020), whereas many more smaller and lighter weights, such as those frequently used from c. $1750 \mathrm{cal} \mathrm{BC}$ onwards, would have been needed to create a textile of a similar size.

Cabezo Redondo, one of the few Bronze Age sites to have been extensively excavated, has yielded the greatest amount of information on the subject of loom weights. Here, various concentrations of cylindrical weights have been found in many buildings, and in open spaces used for circulation (Soler, 1987; Hernández et al., 2016) (Figure 9). Of particular note are two groups of about fifty loom weights associated with carbonized timbers in two dwellings, House XVIII and within the circulation space close to House XXVII. Another group of thirty-six weights was found in House XV. Groups of weights associated with carbonized timbers have also been recovered in Castellón Alto (Contreras, 2000: 129) and El Rincón de Almendricos (Ayala, 1991: 174).

Concentrations of loom weights have also been found next to entranceways; as at Peñalosa, next to the entrances of houses IV and VI. The entrance of the latter house is directly connected to a yard that produced evidence for metallurgical production (Contreras, 2000: 132, note 2).

This association of groups of loom weights with passageways, open spaces, and with some of the larger buildings in the settlements, where a number of other production activities took place, is quite common. Another good example is provided by Building $\mathrm{H} 1$ at Tira del Lienzo (Lull et al., 2015a: 194): there, loom weights were found alongside grinding tools, various vessels, and silverwork (Delgado-Raack et al., 2015).

\section{Discussion}

When attempting to gain an insight into the everyday life of prehistoric groups through archaeology, it is essential to characterize the ways in which these communities organized their production and consumption, understand how activity areas were structured and associated with domestic units, and document the distribution of goods inside settlements and within a region.

The presence of spindle whorls, loom weights, looms, and graves containing the remains of garments or linen cloth in many excavated settlements, regardless of their size, location, or economic standing, suggests that the processes associated with spinning, weaving, and making textiles were normal everyday tasks, some of them seasonal in nature (Bender Jørgensen et al., 2018: 71-73). We therefore do not believe that there was craft specialization or specific storage sites in the eastern Iberian Peninsula in the Bronze Age, in contrast to the situation in other parts of the Eastern Mediterranean and Mesopotamia (McCorriston, 1997; Killen, 2007; Nosch et al., 2012). To date, we have no evidence for the existence of exchange systems, although it is presumed that these did exist. Nor is it possible to suggest how production was organized, for example whether each domestic group was self-sufficient and produced its own textiles and garments, or whether some activities, including textile manufacture, were managed collectively within each settlement, or even whether textile production, distribution, and exchange were largely controlled by the elite, given the social value of fabrics.

It appears that, in extensively excavated settlements, only a few areas (generally no more than two or three) show clear evidence of activities associated with textile production. This would speak against individual households being self-sufficient (Jover et al., 2020), since it indicates a concentration of textile production only in certain areas of each settlement. 


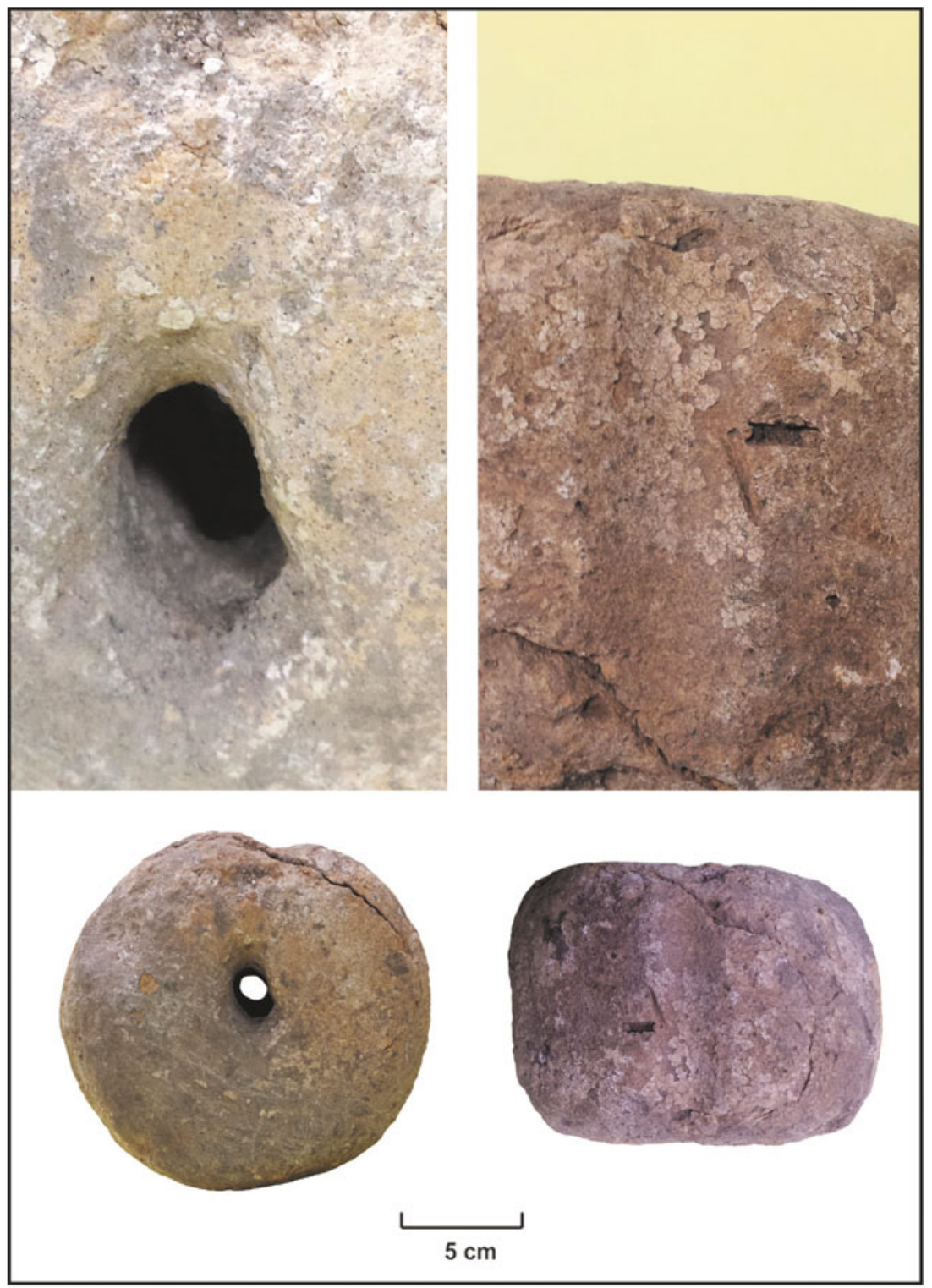

Figure 9. Cylindrical loom weight from Cabezo Redondo with suspension wear.

Nevertheless, these few textile production areas are not sufficiently large to indicate specialized workshops; moreover, they share space with other household production and consumption activities. To better resolve such questions of spatial organization, we must first endeavour to acquire more and better-quality data on the depositional and post-depositional history of the contexts excavated.

Studies of the faunal remains from both small and large settlements indicate an intensive use of the secondary products derived from domestic livestock, including wool (Andúgar \& Saña, 2004; Rizo, 2009), even though flock management was 
not exclusively geared towards the production of wool. This suggests that the composition and management of herds was probably controlled by each domestic or family group and designed to meet their wide-ranging needs, at least in part.

The flax stems and seeds from most of the extensively excavated settlements indicate that the cultivation of flax was probably widespread, taking advantage of the favourable growing conditions in the south-eastern Iberian Peninsula. We therefore propose that there was a high level of use of other plant fibres, such as esparto, reed, and rushes for basketry, ropes, construction material, and clothing. These plant species are abundant, easily and widely accessible in many areas of the south-eastern Iberian Peninsula and were therefore likely to be available to domestic or family groups and communities.

It should thus not be surprising that looms or other evidence of textile production have been found in almost all types of sites: farms or villages located on the plain, such as Rincón de Almendricos and Los Cipreses (Ayala, 1991), small fortified settlements, such as Caramoro I (Jover et al., 2019), medium-sized settlements with clearly diverse production activities, such as Castellón Alto (Contreras et al., 2000) and Peñalosa (Contreras, 2000), and large central settlements such as El Argar (Siret \& Siret, 1890) and Cabezo Redondo (Hernández et al., 2016).

The oblong loom weights with four perforations can provide us with a number of interesting insights. Taking into account the seasonality of textile production (Bender Jørgensen et al., 2018: 7173), the fact of finding these loom weights in large groups, and in numbers that far exceed what would be required for just one vertical loom, leads us to consider that the looms were not permanently set up and that elements of the loom, such as the weights, would have been stored somewhere within the domestic space. Furthermore, and even more importantly, these large groups of weights may also indicate the spaces where the domestic groups stored possibly all of their textilemaking equipment, to be deployed among members of communities when textile production was required (Basso, 2018b, 2020).

The same may also be true for the manufacturing areas. The best example of the possible centralization of the production of implements associated with textile work is found in El Argar. Here, the Siret brothers excavated two groups of 600 loom weights-500 and 100, respectively - which had been abandoned during the firing process (Siret \& Siret 1890: 157). Although they were small and light loom weights, the numbers found greatly exceeded the number of weights required for a loom, even a large one.

Vicente Lull (1983: 255) interpreted this as clear evidence of labour specialization. Without ruling out this interpretation, we believe that this at least indicates the concentration and centralization of the means of production, either during the manufacture of these weights or their subsequent storage for later distribution within the household or community (Basso, 2018b: 61).

On several extensively excavated sites, including Peñalosa (Contreras, 2000: 129) and Tira del Lienzo (Lull et al., 2015a), textile production areas shared the same space as other craft activities of high social value, such as metallurgy and jewellery production. There is also evidence that loom weights were stored in large buildings where cereals were processed and stored, as in Lloma de Betxí (De Pedro, 1998). The finding of a loom alongside evidence of grain processing and other craft activities within the largest room at E1 Cerro del Cuchillo (Hernández \& Simón, 1993) constitutes a further 
example. This tendency to concentrate activities in a single building or room that appears to be associated with greater control over textile production processes, coincides in time and space with marked changes in space management within settlements (López Padilla \& Jover, 2014).

This period of change observed in settlements seems to coincide with a progressive standardization among certain textile tools, such as loom weights and spindle whorls. Around 1800/1750 cal BC, oblong loom weights disappeared, as new types emerged. Cylindrical loom weights began to dominate the archaeological record, at first with two perforations, finally giving way to a single central perforation. Concurrently, biconical ceramic spindle whorls became common. All these technological changes indicate not only a major standardization in textile tools but also the introduction of improvements in textile production and, possibly, a higher degree of craft specialization.

\section{Conclusions}

More than a century of archaeological research on the Bronze Age in the eastern Iberian Peninsula has led to the definition of different archaeological cultures, with differing degrees of social and economic development. Among these, the Argaric culture stands out for the size of its settlements, the investments made in large-scale infrastructure works, and a marked degree of ritual behaviour (Lull, 1983; Cámara, 2001; Aranda et al., 2015).

The archaeological evidence shows that, throughout the eastern Iberian Peninsula, there was an in-depth knowledge of the properties of plant and animal fibres used to make clothing, basketry, and ropes. Linen and wool were used to create textiles for clothes, covers, and bags; while other fibres such as bulrushes, and particularly esparto grass, were employed in the manufacture of items associated with storage, transport, protection, furnishing, footwear, etc. This clearly shows the importance of the crafts associated with textile production in the activities and everyday lives of those Bronze Age communities.

The procurement, exchange, and distribution of wool and linen, both fundamentally associated with weaving, and of esparto grass and other similar plant fibres used in basketry and rope work, have several social and economic implications. Wool may have been obtained on a domestic scale by communities or kinship groups raising small flocks of sheep. In this sense, the absence of large flocks, necessary for a supra-domestic consumption (Sabatini \& Bergerbrant, 2019), leads us to propose that wool production was limited to the household sphere and less developed than the production of bast fibres. We also contend that specialized labour did not exist in Bronze Age eastern Iberia, nor did the levels of production and exchange operate on the same scale as, for example, in Mesopotamia (McCorriston, 1997; Algaze, 2008), Egypt (Lucas \& Harris, 1962; VogelsangEastwood, 1992), the Aegean (Killen, 2007; Militello, 2007), or even some parts of Europe, such as northern Italy (Sabatini et al., 2018). Rather, the textile production in our area of study appears to be related to an incipient gender-based division of labour (Lozano et al., 2020) that arose within kinship groups and that, at best, had the potential to promote small-scale exchange processes.

The production of linen, with flax probably cultivated from the third millennium cal $\mathrm{BC}$ onwards in numerous parts of the Iberian Peninsula, appears to have followed a similar trajectory. Flax production, transformation, and exchange may have been more frequent than indicated by 
research conducted so far, as this has focused more on non-perishable objects than on the products of weaving. Research elsewhere in Europe and Mesopotamia (Barber, 1991; Gillis \& Nosch, 2007; Algaze, 2008), clearly shows that the production of clothing played a prominent role in the economy of late prehistoric societies undergoing processes of social and political stratification. The scarce but significant evidence that we have been able to gather in the south-eastern Iberian Peninsula attests to this.

Textile production would only later become a full-time specialized activity in the eastern Iberian Peninsula, with the improvement in transport and the rise of social demands and differentiation. Alongside the continuing household production of fabrics and basketry to meet local needs, specialist craftspeople began to emerge. They specialized in the production of fabrics for the elite that were exceptional for the quality of the thread used, their weaving and treatment, while other people were fully employed in transporting and treating the fibres. In some regions, for example in Lower Mesopotamia, these processes have been recorded from the fourth millennium BC onwards (Algaze, 2008), whereas in the Iberian Peninsula there is insufficient evidence so far to suggest that this was the case.

It would appear that production within kinship groups remained predominant and that the elites had not yet developed the mechanisms required to control the production and distribution of textile goods. Nonetheless, within the Argaric area, the concentration of specific weaving tasks in certain buildings where other socially important activities such as metalworking, silversmithing (Delgado-Raack et al., 2015), and even ivory carving (López Padilla, 2011) were carried out allows us to suggest that the communities of the El Argar culture had taken at least the first steps towards controlling their production and distribution.

\section{AcKNowledgements}

This research was developed within the Prehistory and Protohistory Research Group of the University of Alicante (Spain) (VIGROB-098) and undertaken within the framework of the research project 'Social and frontier spaces during the Chalcolithic and Bronze Age in the Eastern Iberia Peninsula' (HAR201676586-P), funded by the Ministerio de Economía y Competitividad de España. We would like to thank María Pastor Quiles and Dan Miles for revising our text.

\section{REFERENCES}

Alfaro, C. 1984. Tejido y cestería en la Península Ibérica. Historia de su técnica e industrias desde la Prehistoria hasta la Romanización (Bibliotheca Praehistorica Hispana 21). Madrid: CSIC.

Alfaro, C. 2005. Informe de los restos textiles, de cestería y de cuero procedentes de Cueva Sagrada I (Lorca, Murcia). In: J.J. Eiroa, ed. El cerro de la Virgen de la Salud (Lorca). Excavaciones arqueológicas, estudio de materiales e interpretación histórica (Serie arqueológica 5). Murcia: Universidad de Murcia, pp. 229-46.

Alfaro, C. 2012. Spain. In: M. Gleba \& U. Mannering, eds. Textiles and Textile Production in Europe from Prehistory to $A D$ 400. Oxford: Oxford University Press, pp. 334-46.

Algaze, G. 2008. Ancient Mesopotamia at the Dawn of Civilization: The Evolution of an Urban Landscape. Chicago: University of Chicago Press.

Andersson Strand, E. \& Nosch, M.L. eds. 2015. Tools, Textiles and Contexts: Investigating Textile Production in the Aegean and Eastern Mediterranean Bronze Age (Ancient Textiles Series 21). Oxford and Philadelphia: Oxbow Books. 
Andúgar, L. \& Saña, M. 2004. La gestió ramadera durant el II millenni cal BC. Cypsela, 15: 209-28.

Aranda, G., Montón-Subias, S. \& Sánchez Romero, M. 2015. The Archaeology of Bronze Age Iberia: Argaric Societies. New York \& London: Routledge.

Ayala, M.M. 1991. El poblamiento argárico en Lorca. Estado de la cuestión. Murcia: Ayuntamiento de Lorca.

Ayala, M.M. and Jiménez, S. 2007. Útiles de esparto en la Prehistoria reciente: evidencias arqueológicas. In: J.B. Vilar, A. Peñafiel \& A. Irigoyen, eds. Historia y sociabilidad. Murcia: Universidad de Murcia, pp. 171-96.

Barber, E.J.W. 1991. Prehistoric Textiles: Development of Cloth in the Neolithic and the Bronze Ages with Special Reference to the Aegean. Princeton: Princeton University Press.

Basso, R.E. 2018a. La problemática de lo textil en el registro arqueológico. Aspectos teóricos y metodológicos. In: E. Cutillas, ed. Convergencia y transversalidad en bumanidades. Alicante: Universidad de Alicante, pp. 203-09.

Basso, R.E. 2018b. Evidencias de producción textil en un poblado de la Edad del Bronce: revisión del conjunto de pesas de telar del Castell d'Almizra (Camp de Mirra, Alicante). Recerques del Museu d'Alcoi, 27: 49-62.

Basso, R.E. 2019. Los inicios de la artesanía textil en el Medio Vinalopó: las evidencias arqueológicas de la Edad del Bronce. In: J. C. Márquez, R. Navalón-García. \& L. Soler, eds. De la Artesanía a la Industria. Elda: Ayuntamiento de Elda, pp. 401-27.

Basso, R.E. 2020. To Weave or not to Weave: The Oblong-shape Loom Weights in the Early Bronze Age of the Southeast Iberia. In: M. Bustamante-Álvarez, E.H. Sánchez López, J. Jiménez Ávila, eds. Purpureae Vestes VII, Redefining Textile Handcraft: Structures, Tools and Production Processes. Granada: Universidad de Granada, pp. 37-45.

Basso, R.E. \& López, J.A. 2019. Bronze Age Antler and Bone Spindle Whorls in the Southeast of Iberia. Cuadernos de Prehistoria y Arqueología de la Universidad de Granada, 29: 27-40.

Bender Jørgensen L., Sofaer, J. \& Stig Sørensen, M.L. 2018. Creativity in the
Bronze Age: Understanding Innovation in Pottery, Textile, and Metalwork Production. Cambridge: Cambridge University Press. https://doi.org/10.1017/9781108344357

Briard, J. 1997. L'âge du Bronze en Europe. Économie et société 2000-800 avant J.-C. Paris: Errance.

Buxó, R. \& Piqué, R. 2008. Arqueobotánica. Los usos de las plantas en la Peninsula Ibérica. Barcelona: Ariel.

Cámara, J.A. 2001. El ritual funerario en la Prehistoria Reciente en el Sur de la Peninsula Ibérica (British Archaeological Reports International Series 913). Oxford: Archaeopress.

Chapman, R. 1991. La formación de las sociedades complejas. El sureste de la peninsula ibérica en el marco del Mediterráneo occidental. Barcelona: Crítica.

Childe, V.G. 1958. The Prehistory of European Societies. London: Penguin.

Contreras, F. 2000. Proyecto Peñalosa. Análisis bistórico de las comunidades de la Edad del Bronce del Piedemonte meridional de Sierra Morena y depresión Linares-Bailén. Sevilla: Conserjería de Cultura.

Contreras, F., Rodríguez, O., Cámara, J.A. \& Moreno, A. 2000. Hace 4000 años. Vida y muerte en dos poblados de la Alta Andalucía. Jaén: Conserjería de Cultura.

Costin, C.L. 2005. Craft Production. In: H. Maschner \& C. Chippindale, eds. Handbook of Methods in Archaeology. Lanham (MD): AltaMira, pp. 1032-105.

Costin, C.L. 2013. Gender and Textile Production in Prehistory. In: D. Bolger, ed. A Companion to Gender Prehistory. Chichester: Wiley-Blackwell, pp. 180202.

Delgado-Raack, S., Lull, V., Martin, K., Micó, R., Rihuete, C. \& Risch, R. 2015. Espacios de forja en El Argar. El edificio central de Tira del Lienzo (Totana, Murcia). MARQ, Arqueología y Museos, 6: 45-64.

De Pedro, M.J. 1998. La Lloma de Betxí (Paterna, Valencia). Un poblado de la Edad del Bronce (Trabajos Varios del SIP, 94). Valencia: Diputación Provincial.

Earle, T., Ling, J., Uhnér, C., Stos-Gale, Z. \& Melheim, L. 2015. The Political Economy and Metal Trade in Bronze Age Europe: Understanding Regional Variability in Terms of Comparative Advantages and Articulations. European 
Journal of Archaeology, 18: 633-57. https:// doi.org/10.1179/1461957115Y. 0000000008

Fidalgo, D., Silva, A.M. \& Porfírio, E. 2019. Non-Masticatory Dental Wear Patterns in Individuals Exhumed from the Middle Bronze Age Rock-Cut Tombs of Torre Velha 3 (Serpa, Portugal). International Journal of Osteoarcheology, 30: 13-23. https://doi.org/10.1002/oa.2825

Frei, K.M., Mannering, U., Vanden Berghe, I. \& Kristiansen, K. 2017. Bronze Age Wool: Provenance and Dye Investigations of Danish Textiles. Antiquity, 91 (357): 64054. https://doi.org/10.15184/aqy.2017.64

Galán, C. \& Sánchez, Meseguer, J.L. 1994. Santa María del Retamar. 1984-1994. In: J.L. Sánchez Meseguer, C. Galán, A. Caballero, C. Fernández Ochoa \& M.T. Musat, eds. Jornadas de Arqueología de Ciudad Real en la Universidad Autónoma de Madrid (Madrid, 1994). Toledo: Junta de Comunidades de Castilla-La Mancha, pp. 87-110

Gillis, C. \& Nosch, M.L. eds. 2007. Ancient Textiles: Production, Crafts and Society (Ancient Textiles Series 1). Oxford and Oakville (CT): Oxbow Books.

Gilman, A. 1981. The Development of Social Stratification in Bronze Age Europe. Current Anthropology, 22: 1-23.

Gleba, M. 2008. Textile Production in PreRoman Italy. Oxford: Oxford University Press.

Gleba, M. \& Harris, S. 2019. The First Plant Bast Fibre Technology: Identifying Splicing in Archaeological Textiles. Archaeological and Antbropological Sciences, 11: 2329-46. https://doi.org/10.1007/ s12520-018-0677-8

Gleba, M. \& Mannering, U. eds. 2012. Textiles and Textile Production in Europe: From Prehistory to $A D$ 400. Oxford: Oxford University Press.

Harding, A.F. 2000. European Societies in the Bronze Age. Cambridge: Cambridge University Press.

Harris, S. 2012. From the Parochial to the Universal: Comparing Cloth Cultures in the Bronze Age. European Journal of Archaeology, 15: 61-97. https://doi.org/10. 1179/1461957112Y.0000000006

Hernández, M.S. \& Simón, J.L. 1993. El II milenio A.C. en el Corredor de Almansa (Albacete). Panorama y perspectivas. In: J.
Blánquez, R. Sanz \& M.T. Musat, eds. Arqueología en Albacete. Toledo: Conserjería de Cultura, pp. 35-56.

Hernández, M.S., García, G. \& Barciela, V. 2016. Cabezo Redondo (Villena, Alicante). Alicante: Universidad de Alicante.

Hundt, H.J. 1991. Gewebereste aus den frühbronzezeitlichen Gräbern von E1 Argar (Almería). In: H. Schubart \& H. Ulreich, eds. Die Funde der südostspanischen Bronzezeit aus der Sammlung Siret (Madrider Beiträge 17). Madrid: Deutsches Archäologisches Institut, pp. 414-31.

Jover, F.J. \& López, J.A. 2013. La producción textil durante la Edad del bronce en el cuadrante suroriental de la Península Ibérica: materias primas, productos, instrumentos y procesos de trabajo. Zephyrus, 71: 149-71.

Jover, F.J., López, J.A., Machado, M.C., Herráez, M.I., Rivera, D., Precioso, M.L. \& Llorach, R. 2001. La producción textil durante la Edad del Bronce: un conjunto de husos o bobinas de hilo del yacimiento de Terlinques (Villena, Alicante). Trabajos de Prehistoria, 58: 171-86. https://doi.org/ 10.3989/tp.2001.v58.i1.240

Jover, F.J., López, J.A., Pastor, M. \& Basso, R.E. 2020. Modo de vida y racionalidad de la economía campesina: A propósito de las comunidades de la Edad del Bronce de la zona septentrional de El Argar. Historia Agraria, 81: 125-64. https://doi.org/10. 26882/histagrar.081e08j

Jover, F.J., Pastor, M., Basso, R.E., Martínez, S. \& López, J.A. 2019. Secuencia de ocupación y desarrollo constructivo del asentamiento de Caramoro I (Elche, Alicante): aportaciones a la arquitectura argárica. Arqueología de la Arquitectura, 16: e083. https://doi.org/10.3989/arq.arqt.2019.005

Killen, J.T. 2007. Cloth Production in Late Bronze Age Greece: The Documentary Evidence. In: C. Gillis \& M.-L. Nosch, eds. Ancient Textiles: Production, Crafts and Society (Ancient Textiles Series 1). Oxford: Oxbow Books, pp. 50-58.

Kristiansen, K. \& Larsson, T.B. 2005. The Rise of Bronze Age Society: Travel, Transmissions and Transformations. Cambridge: Cambridge University Press.

López Mira, J.A. 1995. La actividad textil durante la Edad del Bronce en la provincia de Alicante: las fusayolas. In: XXI 
Congreso Nacional de Arqueología (TeruelAlbarracín 1991), vol. 3. Zaragoza: Diputación General de Aragón, pp. 78598.

López Padilla, J.A. 2011. Asta, hueso y marfil. Artefactos óseos de la Edad del Bronce en el Levante y Sureste de la Península Ibérica (c. 2500-c. 1300 cal BC). Alicante: Museo Arqueológico de Alicante.

López Padilla, J.A. \& Jover, F.J. 2014. Cabezo Pardo. Una aldea de campesinos en el confín de El Argar. In: J.A. López Padilla, ed. Cabezo Pardo (San Isidro /Granja de rocamora, alicante). Excavaciones arqueológicas en el yacimiento de la Edad del Bronce. Alicante: Museo Arqueológico de Alicante, pp. 395-409.

Lozano, M., Jiménez-Brobeil, S.A., Willman, J.C., Sánchez-Barba, L.P., Molina, F. \& Rubio, Á. 2020. Argaric Craftswomen: Sex-Based Division of labor in the Bronze Age south-eastern Iberia. Journal of Archaeological Science: 105239 (corrected proof in press, 29 September 2020). https://doi.org/10.1016/j.jas.2020.105239

Lucas, A. \& Harris, J.R. 1962. Ancient Egyptian Materials and Industries (4th ed). London: Edward Arnold.

Lull, V. 1983. La 'cultura' de El Argar. Un modelo para el estudio de las formaciones económico-sociales prehistóricas. Barcelona: Akal.

Lull, V., Micó, R., Rihuete, C. \& Risch, R. 2009. El Argar: la formación de una sociedad de clases. In: M.S. Hernández, J.A. Soler \& J.A. López, eds. En los confines del Argar. Una cultura de la Edad del Bronce en Alicante. Alicante: Museo Arqueológico de Alicante, pp. 224-45.

Lull, V., Micó, R., Rihuete, C. \& Risch, R. 2015a. La Bastida y la Tira del Lienzo (Totana, Murcia) (Ruta argárica 1, Guías arqueológicas). Murcia: Integral Sociedad para el Desarrollo Rural.

Lull, V., Micó, R., Rihuete, C., Risch, R., Celdrán, E., Freigeiro, M.I., et al. 2015b. La Almoloya (Totana, Murcia) (Ruta argárica 2, Guías arqueológicas). Murcia: Integral Sociedad para el Desarrollo Rural.

McCorriston, J. 1997. The Fiber Revolution: Textile Extensification, Alienation and Social Stratification in Ancient Mesopotamia. Current Anthropology, 38: 517-35.
Militello, P. 2007. Textile Industry and Minoan Palaces. In: C. Gillis \& M.-L. Nosch, eds. Ancient Textiles: Production, Crafts and Society (Ancient Textiles Series 1). Oxford: Oxbow Books, pp. 36-45.

Molina, F., Rodríguez-Ariza, M.O., JiménezBrobeil, S. \& Botella, M. 2003. La sepultura 121 del yacimiento argárico de El Castellón Alto (Galera, Granada). Trabajos de Prehistoria, 60: 153-58. https://doi.org/10.3989/tp.2003.v60.i1.127

Nosch, M.-L., Koefoed, H. \& Andersson Strand, E. eds. 2012. Textile Production and Consumption in the Ancient Near East: Archaeology, Epigraphy, Iconography (Ancient Textiles Series 12). Oxford and Oakville (CT): Oxbow Books.

Rafel, N. 2007. El textil como indicador de género en el registro funerario ibérico. In: P. González, C. Masvidal, S. Montón \& M. Picazo, eds. Interpreting Household Practices: Reflections on the Social and Cultural Roles of the Maintenance Activities (Treballs d'Arqueologia, 13). Bellaterra: Universitat Autonòma de Barcelona, pp. 115-46.

Risch, R. 2002. Recursos naturales, medios de producción y explotación social. Un análisis económico de la industria lítica de Fuente Álamo (Almería) 2250-1400 antes de nuestra era (Iberia Archaeologica 3). Mainz am Rhein: Philipp von Zabern.

Rizo, C.E. 2009. Ganadería y caza durante la Edad del Bronce. Arqueozoología del Tabayá (Aspe, Alicante). Villena: Fundación José María Soler.

Rodríguez-Ariza, M.O. \& Guillén, J.M. 2007. Museo de Galera. Guía Oficial. Granada: Ayuntamiento de Galera.

Romero, A. 2016. Antropología dental de los individuos de Cabezo Redondo. In: M.S. Hernández, G. García \& V. Barciela, eds. Cabezo Redondo (Villena, Alicante). Alicante: Universidad de Alicante, pp. 85-86.

Sabatini, S. \& Bergerbrant, S. 2019. The Textile Revolution in Bronze Age Europe: Production, Specialisation, Consumption. Cambridge: Cambridge University Press. https://doi.org/10.1017/9781108656405

Sabatini, S., Earle, T. \& Cardarelli, A. 2018. Bronze Age Textile \& Wool Economy: The Case of the Terramare Site of Montale, Italy. Proceedings of the Prehistoric Society. 84: 359-85. https://doi.org/10. 1017/ppr.2018.11 
Siret, E. \& Siret, L. 1890. Las Primeras Edades del Metal en el Sudeste de España. Barcelona: s.n.

Soler, J.A., López, J.A., Roca, C., Benito, M. \& Botella, M.C. 2008. Sepultura infantil de la Edad del Bronce de Monte Bolón. In: R. Azuar, ed. Elda. Arqueología y museo. Alicante: Museo Arqueológico de Alicante, pp. 16-37.

Soler, J.M. 1987. Excavaciones arqueológicas en el Cabezo Redondo. Alicante: Instituto Juan Gil-Albert.

Vogelsang-Eastwood, G. 1992. The Production of Linen in Pharaonic Egypt. Leiden: Textile Research Centre.

\section{Biographical Notes}

Ricardo E. Basso Rial is a $\mathrm{PhD}$ student at the University of Alicante. His research focuses on textile production in the Iberian Peninsula in prehistoric and Bronze Age communities.

Address: Instituto Universitario de Investigación en Arqueología y Patrimonio Histórico, Universidad de Alicante, Carretera de San Vicente, s/n, 03690 San Vicente del Raspeig, Spain. [email: ricardo.basso@ua.es]. ORCID: 00000002-5323-2281.
Francisco Javier Jover Maestre is director of the Research Institute of Archaeology and Heritage and professor of prehistory at the University of Alicante. His work centres on the first agrarian communities in the east and the south-east of the Iberian Peninsula.

Address: Instituto Universitario de Investigación en Arqueología y Patrimonio Histórico, Universidad de Alicante, Carretera de San Vicente, s/n, 03690 San Vicente del Raspeig, Spain. [email: javier. jover@ua.es]. ORCID: 0000-0001-52132361.

Juan Antonio López Padilla is an archaeologist at the Archaeological Museum of Alicante. His research focuses mainly on the study of historical process as revealed by bone artefacts in the east and southeast of the Iberian Peninsula during the third and second millennia BC.

Address: Museo Arqueológico Provincial de Alicante, plz. Gómez Ulla, s/n, 03013, Alicante, Spain. [email: japadi@diputacionalicante.es]. ORCID: 0000-0002-15064731.

\section{Une ressource archéologique sous-évaluée : considérations sociales sur la production textile à l'âge du Bronze dans l'est de la péninsule ibérique}

L'âge du bronze en Europe a été considéré, selon Childe, comme le premier "âge d'or " de l'histoire européenne. Les développements en métallurgie clairement associés à la production d'armes et l'expansion des réseaux d'échanges de toutes sortes de biens ont été considérés comme essentiels à la consolidation des élites sociales et, par extension, des inégalités sociales. Toutefois, la production textile n'a pas été suffisamment appréciée, ni en tant qu'artisanat spécialisé, ni en tant que processus de production créant des différences culturelles et révélant des dissymétries sociales. La production textile de l'est de la péninsule ibérique a été sous-évalué car elle appartient à des contextes domestiques et non à des ateliers spécialisés. Dans cet article, nous analysons les données relatives à cette production, qui pourrait avoir joué un rôle important au sein des sociétés dans un processus de stratification sociale. Translation by José María Moreno Narganes.

Mots-clés: production textile, âge du Bronze, péninsule ibérique orientale, lin, laine, alfa 


\section{Eine unterbewertete archäologische Quelle: soziale Aspekte der bronzezeitlichen Textilproduktion auf der östlichen iberischen Halbinsel}

Laut Childe, gilt die Bronzezeit in Europa als das erste "Goldene Zeitalter" in der europäischen Geschichte. Die Entwicklung der Metallurgie, die eindeutig mit der Herstellung von Waffen verbunden ist, und der Ausbau der Austauschnetzwerke für alle Arten von Waren werden als wesentliche Faktoren in der Konsolidierung der sozialen Eliten und im weiteren Sinne der gesellschaftlichen Ungleichheiten angesehen. Die Bedeutung der Textilproduktion wurde jedoch als Spezialhandwerk und Herstellungsprozess, die kulturelle Unterschiede schaffen und soziale Ungleichheiten abgrenzen, unterbewertet. Die archäologischen Beweise für die Textilproduktion auf der östlichen iberischen Halbinsel wurden aufgrund ibrer Verbindung mit bäuslichen Kontexten und nicht mit spezialisierten Werkstätten unterbewertet. Hier untersuchen wir die Textilproduktion und ibre potenziell wichtige Rolle in Gesellschaften, welche in einem Prozess der sozialen Schichtung eingebunden waren. Translation by María Pastor Quiles.

Stichworte: Textilproduktion, Bronzezeit, ost-iberische Halbinsel, Leinen, Wolle, Espartogras 